\title{
A behavior model of willingness to pay for air improvement projects
}

\section{Un modelo de comportamiento que explica la disposición a pagar por proyectos de mejora de la calidad del aire}

\author{
Milton M. Inostroza ${ }^{1}$, Loretto Saavedra ${ }^{2 *}$, Viviana Poblete ${ }^{3} \&$ Alejandra Bahamondez $^{4}$.
}

\footnotetext{
${ }^{1}$ Doctoral student, Facultad de Administración y Economía, Universidad de Santiago, Santiago, Director, Ingeniería Comercial, Universidad de Talca, Chile

2 Doctoral student, Facultad de Administración y Economía, Universidad de Santiago, Santiago, Chile.

${ }^{3}$ Ingeniera Comercial, Graduated of the Facultad de Economía y Negocios, Universidad de Talca, Talca, Chile.

${ }^{4}$ Ingeniera Comercial, Graduate of the Facultad de Economía y Negocios, Universidad de Talca, Talca, Chile.

* Corresponding author: loretto.saavedraqusach.cl
}

\section{ABSTRACT}

Environmental problems are increasingly frequent. They are no longer interpreted as a problem resulting exclusively from production processes but rather a problem of individual behavior and perception. This study proposes a behavior model that measures individuals' willingness to pay (WTP) for improved air quality via a firewood certification program. We surveyed 776 people and found that individuals exhibit favorable behavior toward the environment based on the previous knowledge they have about environmental issues. We suggest that more information needs to be provided to the population so that they have a greater understanding about environmental problems, thus encouraging behaviors that are more favorable toward the environment. Such actions will allow for decontamination programs, like the one outlined in this study, to be more readily supported and implemented.

Keywords: Consumer behaviour, willingness to pay, air quality.

\section{RESUMEN}

El problema medio ambiental es cada día más frecuente, en cuya composición, si bien es cierto se aprecian dimensiones asociadas al proceso productivo, éste es más bien un problema de percepciones y comportamiento. De esta forma, el objetivo de este trabajo es proponer un modelo de comportamiento, que permita medir la disposición a pagar de las personas por un mejoramiento en la calidad del aire vía el uso de leña certificada. La metodología incluyó la aplicación de un instrumento consistente en una encuesta, la cual fue aplicada a un total de 776 personas. La investigación permite concluir que existe un comportamiento favorable de las personas hacia el medio ambiente, a través del conocimiento que poseen. Una medida efectiva sería otorgar mayor información a la población respecto de la real situación medio ambiental de la ciudad, buscando que tomen conciencia de la magnitud del problema y se comporte de manera favorable, accediendo a la implementación de programas de contaminación como el expuesto en el estudio.

Palabras clave: Comportamiento del consumidor, disposición a pagar, calidad del aire. 


\section{INTRODUCTION}

Santiago, Chile has many well-known problems with pollution, particularly air pollution. In recent years, the population has become more aware of pollution problems and more knowledgeable about its causes and remedies. That said, wood burning stoves continue to be a prevalent form of heating household. Many cities in Chile are greatly affected by air pollution, particularly in the winter months when temperatures drop and wood stoves are used more frequently. These stoves emit high levels of particulate matter (PM10), often at levels higher than legally permitted.

Cerda and Garcia (2010) estimated a first difference time series model with lags for the year 2006. The dependent variable of their study was doctor visits for respiratory illness. PM10, low, average, and high temperatures, humidity, and doctor visits by patients with chronic respiratory problems were the independent variables. Their results indicate that doctor visits for respiratory illness can best be explained by particulate matter, low temperatures, and preexisting respiratory illness. The estimated elasticity of doctor visits to PM10 in their study was 1.43 . With a hypothetical reduction of PM10 by $66.69 \%$, at which point the country would be complying with its latency standards, the population would experience an annual savings of 163.6 million Chilean pesos.

This finding does not necessarily reflect the total value of improving air quality: it represents a minimum threshold. The aim of our study is to propose a behavior model that allows us to measure individuals' willingness to pay (WTP) for improved air quality by buying firewood from an authorized firewood-certifying agency.

This article is divided into four section. First, in the literature review, we present findings from important studies related to WTP and consumer behavior, along with some data on the current situation in Chile. Next, in the methodology section, we outline our conceptual framework, estimation models, characteristics of the survey, and a description of the sample. In the following section, we analyze the results. Finally, we present our conclusions in the last section.

\section{LITERATURE REVIEW}

Cerda et al. (2010) analyzed the differences in willingness to pay (WTP) for improved air quality between users and nonusers of firewood in the La Florida neighborhood of Talca,
Chile. They used a valuation method based on a double dichotomous format, which assumes a linear function and logistical distribution. With this method, they determined the WTP for better air quality by funding a firewood-certifying agency. The WTP they obtained was high enough to cover the costs of the certifying agency, providing evidence that the city could impose a municipal fee for said agency. Their study also found that people who use firewood have a lower WTP than those who do not use it.

Contingent valuation is one of the most commonly used methods for evaluating WTP for environmental goods. This method gained traction in academic literature on environmental economics when two important components of total economic value where introduced: choice value and existence value (Fattahi Ardakani et al., 2017). Contingent valuation is particularly useful for measuring the existence value that individuals assign to natural resources (Tyrväinen \& Väänänen, 1998; Vesely, 2007; Bernath \& Roschewitz, 2008; Jim \& Chen, 2006; Brander \& Koetse, 2011).

Contingent valuation involves studying individuals' preferences for environmental goods or services (Mitchell \& Carson, 1989). Following economic principles, it presents survey takers with a hypothetical situation related to the environment. To complete the survey, participants must decide whether or not to dedicate part of their income to improving air quality. In the survey, participants respond to a series of questions, including the maximum amount of money they would be willing to pay to avoid negative environmental impacts (Lo, A. Y, \& Jim, C, 2015). Contingent valuation has been established as a preferred methodology for studies like this one because it asks participants to explicitly indicate the value they assign to the good or service in question (Bostan, et al., 2020).

\section{Factors that influence willingness to pay}

Environmental problems are increasingly frequent. They are no longer interpreted as exclusively a problem resulting from production processes (although those processes continue contributing to the issue) but rather a behavioral problem. For example, Tikka et al. (2000) assert that countries' environmental problems are fundamentally driven by individuals' behavior and thought patterns.

Studies on consumer buying behavior have mainly focu- 
sed on explaining consumer attitudes using models based on latent variables. These variables are not directly observed but rather represent a mental abstraction formed through the perception of a phenomenon. These variables can be defined in conceptual terms, but they cannot be measured directly or without error. That said, they are useful for simplifying and synthesizing the complex phenomena present in a system (Kinnear \& Taylor, 1998).

It is possible to determine individuals' behavior in relation to the environment. Contingent valuation can explain an individual's WTP by measuring different factors related to environmental improvements.

We can measure the following factors to determine an individual's relationship with air quality:

- Social norms: The rules of conduct and behavior models imposed by a society. These proceed the customs, traditions, and value systems that are continually developed in a society (Rommetveit, 1967). Social norms implicitly influence individuals' attitudes and behaviors.

- Perception: The process by which individuals organize and interpret sensory inputs as a way of giving meaning to their surroundings (Robbins, 1998).

- Attitudes: These are permanent perceptive processes based on knowledge; they are evaluative and action-oriented with respect to an object or phenomenon. There are three main kinds of attitudes: cognitive, affective, and behavioral (Kinnear \& Taylor, 1998).

- Behavior: The word 'behavior' generally refers to the actions of an object in relation to its environment or a particular stimulus. Behavior can be conscious or unconscious, public or private, and voluntary or involuntary (Ardila \& Otros. 1998).

\section{Protest responses}

Protest responses are the reasons participants give for not being willing to pay for an environmental improvement. In some cases, they have an inverse relationship with WTP.

According to the literature on protest responses, there are two kinds of protest bids (Lindsey, 1994). First, there are individuals who state their willingness to pay is zero even though their real WTP is higher than zero (zero protests). Second are individuals who declare a value that is higher than their real WTP.

There are three main reasons why individuals do not express their true WTP (Boyle, 2003):

- An individual does not understand the question being asked but responds to it anyway.

- When faced with this kind of question, an individual act strategically hoping that the proposed exchange will be paid for by someone else.

- An individual protest a particular component of the valuation situation.

In Table 1, we provide examples of protest responses to help identify them in the context of contingent valuation

Table 1. Protest responses in contingent valuation.

Jakobsson, Dragun. 2001

The amounts l'm asked

to pay are too high.

I don't want to pay to improve the environment.

Our society has bigger problems than issues with the environment.

Protecting the

environment isn't

important to me.

The government should protect the environment using taxes that we've already paid.

Not enough information is given.

Source: Self elaboration.

In this study, we estimate a model to identify the determinants of WTP for improved air quality. We do this by identifying the relationships between each factor included in the model.

\section{METHODOLOGY}

We collected data using a pre-coded, structured, self-ad-

Strazzera et al. 2003
The payment method
is inappropriate.

It's not fair that I have to pay pay for a clean environment.

The advantages of a clean environment aren't significant enough that I would pay for them. 
ministered survey. The survey was first piloted with 80 people, which allowed us to refine and finalize the final instrument.

Our survey is divided into three parts. The first part includes a group of underlying factors that significantly influence individuals' willingness to pay. There are eight sections in this part, each constructed using unidimensional, standardized scales (Díaz \& Núñez, 2003). Five of the sections use a Likert scale. In these sections, we attempt to measure the level of prior knowledge the participants have about the environment, their opinion of environmental social norms, their attitude about the environment, and their current satisfaction with the environment. In the other three sections, we used differential semantic scales, which allow participants to define the topics being studied using dichotomous words or phrases (Kinnear, 1998). These scales measure how much responsibility participants believe public and private companies and the general public should have in environmental problems. In each of the section, we also added questions that are directly related to the study's objectives.

In the second part of the survey, there are two sections. The first is a series of open, closed, and dichotomous questions related to the participants' willingness to pay for improved air quality. It also includes questions that identify protest responses. The second section gathers demographic data from the participants.

\section{Samples}

For this study, we use two proportionally stratified samples. Sample A is composed of people who use wood burning stoves or heaters in their homes, while sample B contains people who do not use a wood burning stove or heater in their home.

We designed our survey for men and women above the age or 18 whose households are located in the south-west part of Talca, Chile. We separated the results by socioeconomic segments (SES): ABC1, C2, C3, D, and E.

Since we did not run preliminary studies to determine the size of each of our samples, we assume maximum varian$c e$, where the $p$ and $q$ values are both 0.5 . The confidence interval is $95 \%$, which equals an estimated $Z$ value of 1.96 . The standard error is $5 \%$.

Each of our samples is composed of 388 people over 18 years old.

\section{Table 2. Socioeconomic status and neighbor- hoods included in the study.}

\begin{tabular}{|c|c|c|}
\hline SES & $\begin{array}{l}(\%) \text { of the } \\
\text { total sample } \\
(\mathrm{N}=388)\end{array}$ & Neighborhood \\
\hline ABC1 & $10 \%$ & $\begin{array}{l}\text { Villa Jardín, Villa } \\
\text { Universitaria, Villa } \\
\text { Santa María de Colín }\end{array}$ \\
\hline $\mathrm{C} 2$ and $\mathrm{C} 3$ & $45 \%$ & $\begin{array}{l}\text { Villa Los Naranjos, } \\
\text { Villa Los Paltos, Villa Los } \\
\text { Robles, Villa Los } \\
\text { Ciruelos, Villa Galilea A, B } \\
\text { y C, Villa Los Tilos, Villa } \\
\text { Los Almendros, Villa } \\
\text { Los Castaños }\end{array}$ \\
\hline $\mathrm{D}$ and $\mathrm{E}$ & $45 \%$ & La Florida \\
\hline
\end{tabular}

Source: Self elaboration.

Image 1: Georeferencing of the surveyed area.

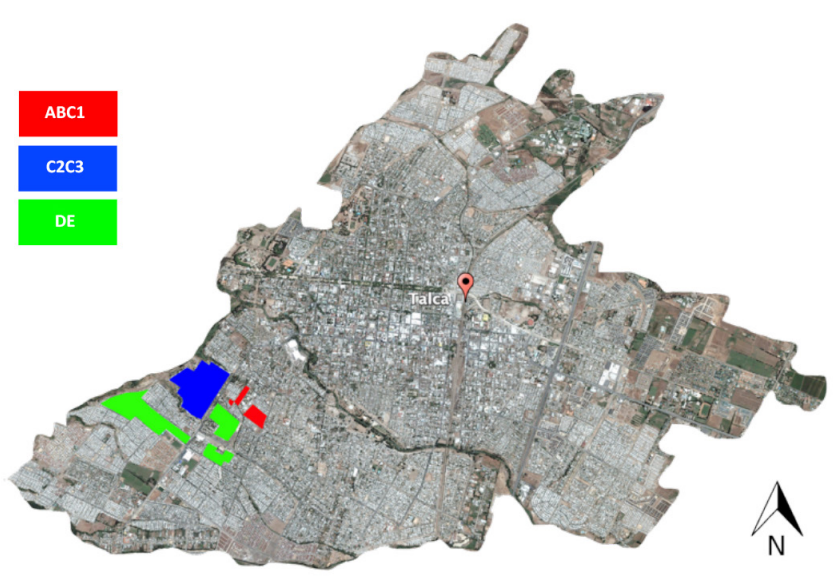

Fuente: Mapa obtenido de Google Earth, según imagen del 31/12/07. 
Table 3. Number of participants by SES and sample group.

\begin{tabular}{lcc}
\hline SES & $\begin{array}{c}\text { Sample A, with wood } \\
\text { burning stove } \\
\text { or heater }\end{array}$ & $\begin{array}{c}\text { Sample B, } \\
\text { no wood burning } \\
\text { stove or heater }\end{array}$ \\
\hline ABC1 & 38 people & 38 people \\
C2 and C3 & 175 people & 175 people \\
$D$ and E & 175 people & 175 people \\
\hline
\end{tabular}

Source: Self elaboration.

\section{RESULTS AND DISCUSSION}

To analyze each of the factors and demographic variables, we used SPSS software, which allowed us to conduct descriptive and inferential analyses of the data. In this section, we will detail each of the analyses we ran.

By analyzing the contingency tables, we can identify dependency and/or interdependency among the demographic variables and the participants' willingness to participate in the certified firewood project. This analysis also helps us construct one part of the explanatory model.

To simplify the multiple and complex relationships between variables from the different sections of the survey, we ran a factorial analysis. This analysis allows us to identify common dimensions or factors that are not apparently related to the variables that make up each of the factors but that certainly affect the WTP explanatory model. We also ran a correlations analysis to measure the extent of association between variables, thus isolating the true explicatory model of this study.

Table 4. Descriptive analysis of the sample.

\begin{tabular}{lcc}
\hline Variable & Characteristic & Relative frequency \\
\hline \multirow{2}{*}{ SES } & ABC1 & $9,6 \%$ \\
& C2 and C3 & $45 \%$ \\
Gender & D and E & $45 \%$ \\
\multirow{2}{*}{ Age } & Women & $58,6 \%$ \\
& Men & $41,4 \%$ \\
& $18-34$ & $30,2 \%$ \\
& $35-44$ & $28,5 \%$
\end{tabular}

\begin{tabular}{lcc} 
& $45-54$ & $21,8 \%$ \\
& $55+$ & $19,5 \%$ \\
Religion & Catholic & $70,1 \%$ \\
& Evangelical & $9,7 \%$ \\
& Other & 10,8 \\
Occupation & Nonbeliever & $9,7 \%$ \\
& Homemaker & $26,2 \%$ \\
& Executive & $20,2 \%$ \\
& Administration & 19,6 \\
\hline
\end{tabular}

Source: Self elaboration.

\section{Descriptive analysis of the protest responses}

There were 165 people with wood burning stoves or heaters who, in section J of the survey, expressed their unwillingness to participate in the project. In Table 5, we present the most common responses given to explain their unwillingness to participate.

Table 5. Frequency of protest responses, sample A (with a wood burning stove or heater)

\begin{tabular}{llc}
\hline$\#$ & Reason & $\begin{array}{c}\text { Relative } \\
\text { frequency }\end{array}$ \\
\hline 1 & $\begin{array}{l}\text { The city should be } \\
\text { responsible for that. }\end{array}$ & $80 \%$ \\
2 & $\begin{array}{l}\text { I already pay enough for } \\
\text { other things. }\end{array}$ & $75.75 \%$ \\
3 & $\begin{array}{l}\text { I don't have enough money } \\
\text { for this kind of plan. }\end{array}$ & $73.3 \%$ \\
4 & $\begin{array}{l}\text { I don't have enough money } \\
\text { to pay for improved air quality. }\end{array}$ & $68.48 \%$ \\
5 & $\begin{array}{l}\text { The proposed certification } \\
\text { plan isn't enough to } \\
\text { decontaminate the air. } \\
6\end{array}$ & $\begin{array}{l}\text { Paying through a water or } \\
\text { electricity bill is not appropriate. }\end{array}$ \\
7 & $\begin{array}{l}\text { It's unfair to charge for clean air. } \\
\text { The government should protect } \\
\text { the environment using tax money. }\end{array}$ & $57.57 \%$ \\
\hline
\end{tabular}

Source: Self elaboration. 
Of sample B, people who do not have a wood burning stove or heater, 222 said they were not willing to collaborate, providing protest responses in section J of the survey. Table 6 outlines the most frequent reasons given for their unwillingness to participate.

Table 6. Frequency of protest responses, Sample B (no wood burning stove or heater).

\begin{tabular}{|c|c|c|}
\hline \# & Reason & $\begin{array}{l}\text { Relative } \\
\text { frequency }\end{array}$ \\
\hline 1 & $\begin{array}{l}\text { The city should be } \\
\text { responsible for that. }\end{array}$ & $78.3 \%$ \\
\hline 2 & I don't use wood to heat my home. & $77.87 \%$ \\
\hline 3 & I already pay enough for other things. & $71.24 \%$ \\
\hline 4 & $\begin{array}{l}\text { The people who contaminate } \\
\text { should have to pay. }\end{array}$ & $67.26 \%$ \\
\hline 5 & It's unfair to have to pay for clean air. & $61.06 \%$ \\
\hline 6 & $\begin{array}{l}\text { I don't have enough money } \\
\text { for that kind of plan. }\end{array}$ & $58.4 \%$ \\
\hline 7 & $\begin{array}{l}\text { The proposed certification plan } \\
\text { isn't enough to decontaminate the air. }\end{array}$ & $56.6 \%$ \\
\hline 8 & $\begin{array}{l}\text { I don't think the plan will be } \\
\text { successful in this city. }\end{array}$ & $53.1 \%$ \\
\hline 9 & $\begin{array}{l}\text { Paying through a water or } \\
\text { electricity bill is not appropriate. }\end{array}$ & $48.7 \%$ \\
\hline
\end{tabular}

Source: Self elaboration.

In both samples, the most common reason given to explain unwillingness to participate was the same: "The city should be responsible for that."

That said, sample B also had a very high frequency of the response "I don't use wood to heat my home." This indicates that many of them do not want to participate monetarily in the proposed program.

\section{Analysis of pay vectors}

In contingent valuation, pretesting procedures are vital because from them we obtain the pay vectors and WTP distribution. In this study, we conducted an open pilot survey with 80 people. From this pilot, we obtained the upper and lower limits. By running Kolmogorov-Smirnov Normality, Q-Q Plot, and P-P Normal analyses, we observe that the sample quantities are distributed near the hypothetical situation points. Because of that, we can conclude that WTP has a symmetric distribution and assume a logistic distribution.

Next, with the size of each sample at $n=388$ (with and without wood burning stoves), thus a total sample of $\mathrm{N}=776$, we proceeded to determine the pay vectors " $m$ " and the subsamples " $n$ " for each pay vector "bid". With that, we obtained 19 types of surveys differentiated exclusively by the amounts given in the double dichotomous WTP question. For this, we used a DWEABS model that allows us to optimize the vectors with their respective pay ranges and sizes of subsamples. Of the total participants $(\mathrm{N}=776), 391$ were unwilling to collaborate monetarily on the project, leaving 385 participants who were willing to participate.

Of the 162 participants who do not possess a wood burning stove or heater and indicated that they were will not participate in the decontamination plan, 48.8\% responded YES-YES, 18.5\% responded YES-NO, 15.4\% responded NO-YES, and $17.3 \%$ responded NO-NO to the WTP question with the double dichotomous format.

Of the 222 participants who possess a wood burning stove or heater and were in favor of collaborating on the project, 71\% responded YES-YES, 21.6\% responded YES-NO, $16.2 \%$ responded NO-YES, and $10.4 \%$ responded NO-NO to the WTP question.

\section{Factorial and reliability analyses}

To simplify the multiple and complex relationships that can exist between variables in different sections of the survey, we ran a factorial analysis. This allowed us to identify common dimensions or factors that connect seemingly unrelated variables and that ultimately have an effect on the behavioral model.

When running a factorial analysis, it is necessary to first confirm the reliability of each of the scales used and to also verify the Kaiser-Meyer-Olkin measure of sample adequacy and the Bartlett contrast. These latter two show us how adequate the variables are for the factor analysis.

\section{We used the following criteria for these analyses:}

To measure the reliability of the scales, we used the Cron- 
bach alpha, which is highly recommended in the literature. With Cronbach alpha, a model or scale is acceptably reliable when the alpha is equal to or higher than 0.70 (Cronbach, 1998). If an acceptable reliability is not found, there are two alternatives: more variables can be added, or variables that have a low total correlation when corrected for the factor (and, thus, are not determinants in the analysis) can be eliminated.

For the KMO statistics, we hope for a value close to 1 , which indicates that the data are adequate for the factorial model analysis. The Bartlett contrast should be able to reject the null hypothesis of initially uncorrelated variables, therefore showing that the application of factor analysis was appropriate (Pérez, 2005). All of the scales and sections that we analyzed met these conditions.

Image 2: Willingness to pay explanatory model.

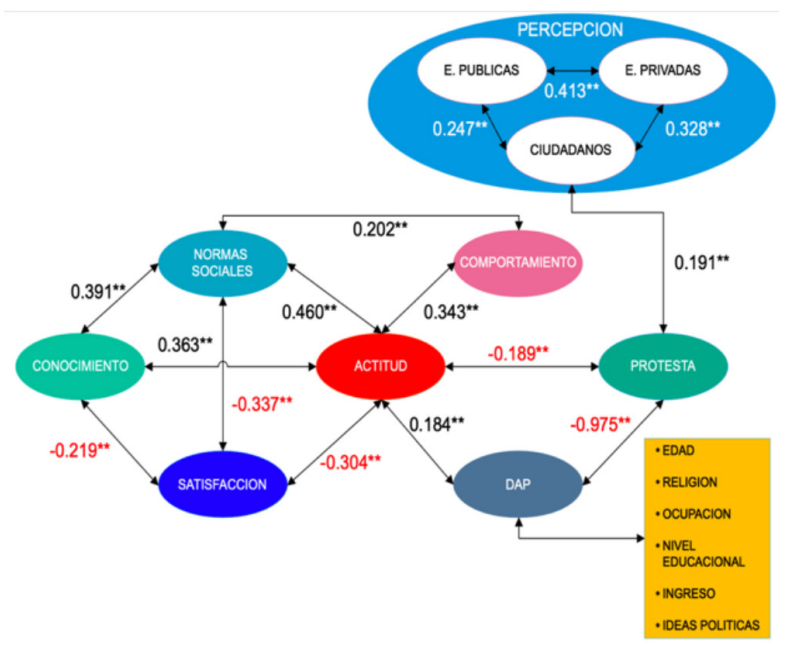

Source: Self elaboration.

\section{Correlation analysis}

To define the WTP explanatory model, we ran a correlation analysis in order to measure the level of association between the different variables.

As shown in the WTP explanatory model (Figure 2), the participants' knowledge of environmental issues is positively correlated with social norms and with individuals' attitudes toward the environment. This indicates that the greater individual's knowledge of the environment, the greater their agreement with social norms and the more positive their attitude towards the environment will be. In contrast, the correlation between knowledge and the satisfaction individuals feel with the current state of the environment is negative (-0.219), which shows that with greater knowledge comes lower levels of satisfaction.

Social norms are positively correlated with behavior (0.202), indicating that the more individuals agree with social norms related to the environment the more favorable their behavior toward the environment will be. There is also a correlation of 0.460 between social norms and people's attitudes toward the environment. This number is very close to a half positive correlation, demonstrating that the more a person agrees with social norms, the more positive their attitude toward the environment will be. The correlation between social norms and satisfaction with the current state of the environment is negative, -0.337 , indicating that the more an individual agrees with social norms, the lower their level of satisfaction will be.

Attitude is positively correlated with behavior and with willingness to participate, with values of 0.343 and 0.184 , respectively. This indicates that the more positive a person's attitude toward the environment, the more favorable their behavior will be and, thus, the more willing to participate they will be. That said, the correlation between attitude and satisfaction and protest responses is negative, indicating that the more positive the attitude, the lower the satisfaction with the current state of the environment and the less likely that the individual will protest participation in the program.

Between the protest responses and willingness to collaborate monetarily with the project, there is a very strong negative correlation of -0.975 ; this is almost a perfect negative correlation. This shows that if an individual shows a high or strong level of protest, they will be less willing to collaborate.

The perception that people have about public and private institutions and the general public are positively correlated, so a person who has a poor perception of private institutions will also likely have a poor perception of public institutions and the general public. Perception of the general public has a positive correlation with behavior, which means that the more favorable a person's perception of the general public, the more positive their behavior towards the environment will be.

Between the protest responses and willingness to collabo- 
rate monetarily with the project, there is a very strong negative correlation of -0.975 ; that is, they move in contrary directions in almost a perfect negative correlation. This indicates that if an individual demonstrates a high level of protest, their willingness to participate will be lower.

In terms of individuals' perception of public and private institutions and the general public, these variables are positively correlated with each other, as seen in the model. This indicates that the three move in the same direction, i.e., if a person has a poor perception of private institutions, they will also have a poor perception of public institutions and of the general public. The variables that have the highest correlation with each other are the perception that individuals have of the general public and the individual's behavior toward the environment, with a positive correlation of 0.191.

If we combine this correlation analysis with the factorial analysis, we can develop many potential scenarios. In the next section, we will highlight the three most common scenarios that influence willingness to collaborate.

\section{Scenario 1}

If a person has knowledge about environmental issues, they will more readily agree with social norms such as buying high-quality products that do not harm the environment, buying firewood from legally established venders, and even reducing their use of firewood. They will also express favorable behaviors toward the environment, i.e., they will take the necessary precautions avoid contaminating, they will donate money to pro-environmentalist institutions, and they will not litter or burn dry leaves. Having a favorable behavior towards the environment leads a person to have a positive perception of social responsibility and a positive image of the general public and public and private companies. Finally, from favorable behavior, a person also adopts a favorable attitude toward the environment and, thus, is more willing to work together with neighbors and to find out the origins and level of moisture in the wood they buy to heat their homes.

All of these characteristics and interrelations lead the person to be more willing to collaborate with the certified firewood project, and, therefore, the likelihood that they respond in protest are dramatically reduced.

\section{Scenario 2}

If a person has knowledge of environmental issues, they will have a positive attitude towards the environment. They will be willing to work together with neighbors and will take into consideration the moisture content and origins of the firewood they use to heat their home. In effect, this positive attitude will lead the person to have a higher willingness to participate in the project and a lower likelihood of protest responses.

\section{Scenario 3}

If a person has knowledge about environmental issues, they will express less satisfaction with the current state of the environment and, therefore, will be more willing to move away from the area in which they are living. Less satisfaction with the current environment translates into a positive attitude toward the environment since people in favor of achieving high satisfaction will be more willing to work together with neighbors and more likely to concern themselves with the origins and moisture level of the firewood they use. This group of interrelated factors will lead the individual to be more willing to collaborate monetarily with the project.

\section{CONCLUSIONS}

Considering that knowledge is directly correlated with social norms and satisfaction, and these are also directly related with individuals' attitudes and behaviors toward the environment, we believe it is possible to increase favorable environmental behaviors in individuals by increasing their knowledge of environmental issues. We suggest that the population should be provided with more information about the current environmental situation in their city. In the case of our study, that would mean more information on air pollution. With an increase in knowledge, the population might become more conscious of the problem and behave in more positive ways, paving the way for decontamination programs like the one outlined in this study.

\section{REFERENCES}

Ardila, R., López, W., Pérez, Andrés., Quiñones, R.y Reyes, Fredy. (1998). Manual de análisis experimental del comportamiento. Editorial Biblioteca Nueva. Madrid, España.

Bernath, K., Roschewitz, A., 2008. Recreational benefits of urban forests: explaining visitors' willingness to pay in the context of the theory of planned behavior. Journal of Environmental Management 89, 155-166. 
Brander, L.M., Koetse, M.J., 2011. The value of urban open space: Meta-analyses of contingent valuation and hedonic pricing results. Journal of Environmental Management 92, 2763-2773.

Bostan, Y., Fatahi Ardakani, A., Fehresti Sani, M., \& Sadeghinia, M. (2020). A comparison of stated preferences methods for the valuation of natural resources: the case of contingent valuation and choice experiment. International Journal of Environmental Science and Technology. doi:10.1007/s13762020-02714-z

Boyle, K. J. (2003). Contingent valuation in practice. In Champ, P.A., Boyle, K. J. and Brown, T. C (Eds.). A primer on nonmarket valuation. Kluwer: Dordrecht.

Cerda, A, et al. (2010). Disposición a pagar para mejorar la calidad del aire en Talca, Chile: comparación entre usuarios y no usuarios de chimeneas a leña. Lecturas de Economía, 72, 195-211.

Cerda, A., y Garcia, L. (2010). Contaminación del aire en la Florida (Talca, Chile): Beneficios económicos en salud por la reducción de los niveles PM10. Revista Medica de Chile 138(11), pp. 1395-1402.

Díaz, M. y Núñez, C. (2003). Análisis de validez de escalas para medir constructos medio ambientales. Universidad de Talca.

Fattahi Ardakani, A., Alavi, C., \& Arab, M. (2017). The comparison of discrete payment vehicle methods (dichotomous choice) in improving the quality of the environment. International journal of environmental science and technology, 14, 1409-1418. doi: $10.1007 / s 13762-017-1246-x$

Jakobsson, K. M., Dragun, A. K (2001). The worth of a possum: Valuing Species with the Contingent Valuation Method. Environmental \& Resource Economics 19.

Jim, C.Y., Chen, W.Y., 2006. Recreation-amenity use and contingent valuation of urban greenspaces in
Guangzhou, China. Landscape and Urban Planning 75, 81-96.

Lindsey, G. (1994). Market models, protest bids, and outliers in contingent valuation. Journal of Water Resources Planning and Management 120.

Lo, A. Y, \& Jim, C. (2015). Protest response and willingness to pay for culturally significant urban trees: Implications for Contingent Valuation Method. Ecological economics, 114, 58-66. doi: 10.1016/j. ecolecon.2015.03.012

Kinnear, T y Taylor. J. (1998). Investigación de mercados. McGraw-Hill Interamericana, S.A. Santa fé de Bogota D.C., Colombia.

Mitchell, R.C., Carson, R.T., 1989. Using Surveys to Value Public Goods: the Contingent Valuation Method Resources for the Future, Washington, D.C.

Robbins Stephen. (1998). Comportamiento organizacional. Octava Edición. Mc Graw-Hill. México.

Rommetveit Ragnar. (1967). Normas y roles sociales. Editorial Paidos. Buenos Aires, Argentina.

Strazzera, E., Genios, M., Scarpa, R. and Hutchinson, W. $G$ (2003). The effect of protest votes on the estimates of WTP for use values of recreational sites. Environmental and Resource Economics 25.

Tikka, P. M. (2000). Effects of educational background on students' attitudes, activity levels, and knowledge. The Journal of Environmental Education 31.

Vesely, E.-T., 2007. Green for green: the perceived value of a quantitative change in the urban tree estate of New Zealand. Ecological Economics 63, 605-615.

Tyrväinen, L., Väänänen, H., 1998. The economic value of urban forest amenities: an application of the contingent valuation method. Landscape and Urban Planning 43, 105-118. 